\title{
Epibenthic fauna dredged from tidal channels in the Wadden Sea of Schleswig-Holstein: spatial patterns and a long-term decline
}

\author{
F. Buhs ${ }^{1,2} \&$ K. Reise ${ }^{1 *}$

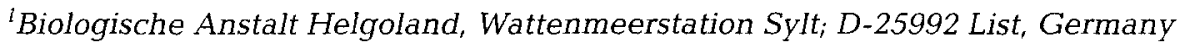 \\ ${ }^{2}$ Abt. Marine Ökologie \& Systematik, Zoologisches Institut der Christian-Albrechts- \\ Universität; D-24098 Kiel, Germany
}

\begin{abstract}
The epibenthic fauna dredged in the channels of the Wadden Sea of Schleswig-Holstein is dominated by crustaceans. Mean species richness is lower in a southern region $(7.6 \pm 2.2$ species haul ${ }^{-1}$ ) which is part of the Elbe estuary and lacks protective barrier islands. A northern region is more marine and is protected by a seaward barrier of high sands and islands. Here mean species richness is $10.9 \pm 2.8$. Within channels, there is no significant inshore-offshore gradient, and species number does not increase with depth. Stratified sampling near the island of Sylt revealed that abundance and diversity are high along the gentle upper slope ( $5 \mathrm{~m}$ depth) of channels when mussels are present, but low in the absence of mussels. Abundance and diversity are also low along the steeper slope below (at 10 and $15 \mathrm{~m}$ depth). In a channel with scattered stones and boulders, highest diversity $(16.0 \pm 5.1)$ and dense epibenthic assemblages were encountered along the upper and middle slopes $(5$ and $10 \mathrm{~m}$ ). Comparisons with historical surveys suggest that a decline of nearly fifty percent of all epifaunal species within the last hundred years may be attributed to fishery disturbances.
\end{abstract}

\section{INTRODUCTION}

Earlier studies described a species-diverse epibenthos for the tidal channels of the Wadden Sea, with beds of eelgrass and oysters, and reefs of mussels and the colonial polychaete Sabellaria spinulosa (Metzger, 1871; Möbius, 1893; Hagmeier \& Kändler, 1927; Hagmeier, 1941). More recent reinvestigations with similar gear revealed the loss of eelgrass, red algae, oysters and Sabellaria-reefs together with some of the associated species (Reise, 1982; Riesen \& Reise, 1982; Reise \& Schubert, 1987; Reise et al., 1989). Furthermore, there appeared to be a long-term decline of sessile and slow-moving epifauna, resulting in an assemblage poor in species. Recurrent anthropogenic disturbances may be the major cause.

A direct test of this assumption was not yet possible, as disturbances such as shrimp fishery and harvesting for mussels is still ubiquitous in this region. Thus, the question arose whether one or more of the tidal inlets in the National Park of the Schleswig-Holstein Wadden Sea should be closed for exploitations to give the epibenthos a chance of recovery, and at the same time to prove the case.

- Addressee for all correspondence

(1) Biologische Anstalt Helgoland, Hamburg 
The purpose of this study is (1) to deliver epifaunal data indicating which of the channel systems may be appropriate candidates for protection or to serve as control sites, (2) to reveal any distributional patterns between and within tidal channels which should be known before a standard monitoring scheme is implemented, and (3) to compare our recent records with previous ones in an attempt to quantify the amount of long-term change in the epifauna.

\section{AREA AND METHODS}

The Wadden Sea of Schleswig-Holstein has an extension of $140 \mathrm{~km}$ and a width of 10 to $20 \mathrm{~km}$ (Fig. 1). The tidal flow passes through 12 major channel systems which infiltrate a total of $1357 \mathrm{~km}^{2}$ of tidal flats. The average length of the channels studied was $21 \pm 6 \mathrm{~km}$ and maximum depths ranged from 11 to $29 \mathrm{~m}$. The tidal inlets seaward of the channels were not included in this survey.

Coastal morphology suggests a subdivision into a southern region from the Elbe river to Eiderstedt peninsula (Dithmarschen Wadden Sea) and a northern region from the latter to the Danish-German border (North Frisian Wadden Sea; Fig. 1). South of Eiderstedt, the rivers Elbe $\left(700 \mathrm{~m}^{3} \mathrm{sec}^{-1}\right)$ and Eider $\left(14 \mathrm{~m}^{3} \mathrm{sec}^{-1}\right)$ discharge into the Wadden Sea, and tidal flats descend without a seaward barrier towards the North Sea. No large rivers enter the northern region, and a barrier of high sands and sandy hooks of two pleistocene islands (Amrum and Sylt) provides some shelter against westerly storms from the North Sea. In the south, the tidal range remains close to $3 \mathrm{~m}$, while in the north it varies locally between 1.8 and $3.5 \mathrm{~m}$. Maximum current velocities during normal tides in the inlets range from 0.7 to $1.0 \mathrm{~m} \mathrm{sec}^{-1}$ in the south and from 1.0 to $1.5 \mathrm{~m} \mathrm{sec}^{-1}$ in the north (Dick et al., 1992).

In July 1988, when our synchronous survey of 12 channel systems was carried out, salinity was 18 to $28 \mathrm{psu}$ in the southern channels and 28 to $30 \mathrm{psu}$ in the northern ones. Fluctuations are generally higher in winter when the average is low, and lower in summer when the average is high (Postma, 1983). The bed of tidal channels is sandy with median grain sizes of 0.06 to $0.25 \mathrm{~mm}$ in the south and 0.5 to $1.0 \mathrm{~mm}$ prevailing in the north (Figge, 1981; own measurements).

Epibenthos was sampled with a traditional oyster dredge of $1 \mathrm{~cm}$ mesh size. The dredge had a wrought iron blade of $1 \mathrm{~m}$ in width at its lower edge. The $0.5 \mathrm{~m}$ long net bag was kept open by a rectangular frame of $1 \times 0.5 \mathrm{~m}$. This gear was used to allow comparisons with earlier surveys in the same region. Our survey of 12 channel systems in July 1988 was carried out by taking 6 hauls of 0.5 nautical miles from the landward to the seaward sections within each channel system. Average depth of hauls was $7.3 \pm 4.5 \mathrm{~m}$ with a range of 0 (low water spring) to $20 \mathrm{~m}$. In May 1992 stratified sampling was performed in channels near the island of Sylt (Lister Ley and Hörnum-Tief; 1 and 2 in Fig.1) by towing the dredge $10 \times 500 \mathrm{~m}$ in 3 parallel rows at depths of $5 \mathrm{~m}, 10 \mathrm{~m}$ and in the deepest part of the channels with a mean depth of $15 \mathrm{~m}$. In July 1992 this survey was repeated, and extended to the Hoyer Dyb (1* in Fig. 1) which together with the Lister Ley branches off the Lister Dyb. Altogether, 72 hauls were taken in 1988 and 150 in 1992. This is equivalent to $142 \mathrm{~km}$ of seabed raked with a dredge of $1 \mathrm{~m}$ in width.

Besides living epibenthos, the dredge content was composed of shell gravel with some stones, and occasionally with clumps of clay or peat. Shell gravel sometimes filled the entire net bag. In these cases, half of the total content was sorted for common 


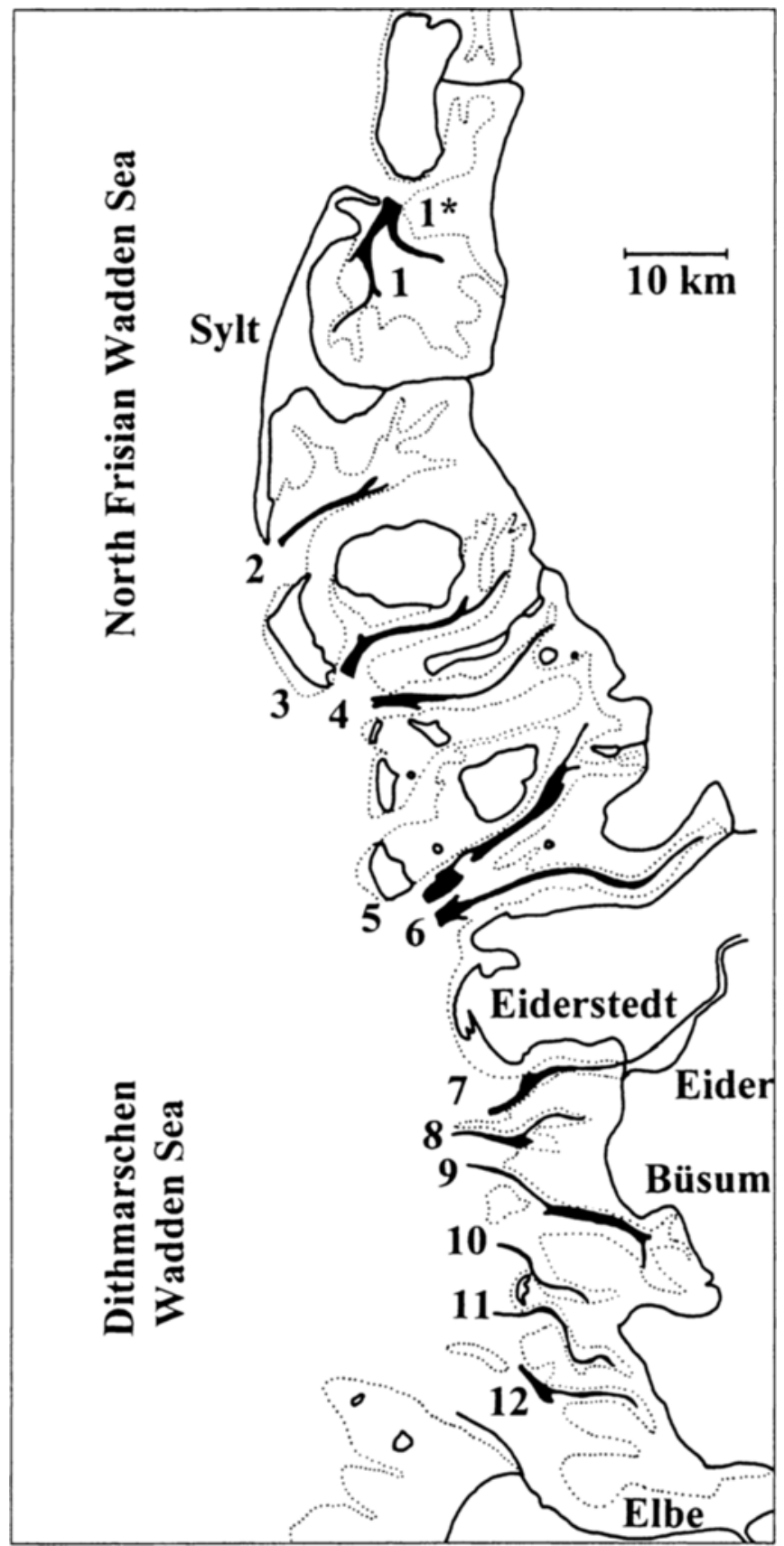

Fig. 1. Wadden Sea of Schleswig-Holstein with surveyed sections of tidal channels (black), sampled in July 1988: 1 Lister Ley, 2 Hörnum-Tief, 3 Norderaue, 4 Süderaue, 5 Norderhever, 6 Heverstrom, 7 Eider estuary, 8 Wesselburener Loch, 9 Norderpiep, 10 Süderpiep, 11 Falsches Tief, 12 Schatzkammer. Sampling during May and July 1992 at 1 and 2; at 1 (Hoyer Dyb) only in July 
species, and counts of individuals were multiplied by 2 . The entire content was then sorted for rare species. Fish were recorded too, but only macrobenthic invertebrates are included in this analysis. Because of their small size, amphipods and mobile polychaetes were disregarded. All barnacles growing on a stone or shell were counted as a 'colony'. Only macroscopic epigrowth on shells, stones and organisms was recorded.

\section{RESULTS \\ Comparison of channel systems}

In the entire survey, 41 taxa were encountered: 12 Cnidaria, 10 Crustacea, 9 Mollusca, 5 Bryozoa, 4 Echinodermata and 1 Porifera. Crustaceans contribute the majority of epifaunal individuals. The number of taxa was 25 in the southern and 35 in the northern region (Table 1). Present in all 12 channel systems were the decapod crustaceans Crangon crangon, Carcinus maenas and Liocarcinus holsatus, barnacles (mainly Balanus crenatus) and the hydroid Obelia longissima. While there were several epifaunal species confined to the northern inlets (i.e. Hyas araneus, Pandalus montagui, Buccinum undatum, Littorina littorea), only one was restricted to the south (the estuarine crab Eriocheir sinensis). Of the dominant taxa, six were significantly more abundant in the north, and only two in the south (C. maenas and Obelia dichotoma; Table 1).

Table 1. Mean and SD of species numbers and abundances of dominant epifauna $(>1 \%)$ in the northern (no. 1-6) and southern (no. 7-12, see Fig. 1) tidal channels of the Wadden Sea of Schleswig-Holstein. * Significant differences (Mann \& Whitney, U-test; P $\leq 0.05$ )

\begin{tabular}{|c|c|c|c|c|c|}
\hline \multirow[t]{2}{*}{ Tidal inlet no. } & \multicolumn{2}{|c|}{$\begin{array}{l}\text { North Frisian } \\
\text { Wadden Sea } \\
1-6\end{array}$} & \multirow[b]{2}{*}{ Sign. } & \multicolumn{2}{|c|}{$\begin{array}{c}\text { Dithmarschen } \\
\text { Wadden Sea } \\
7-12\end{array}$} \\
\hline & Mean & $\mathrm{SD}$ & & Mean & $\mathrm{SD}$ \\
\hline Species per haul & 10.9 & $\{2.8\}$ & - & 7.6 & $(2.2)$ \\
\hline Species per inlet & 19.3 & $(2.9)$ & - & 13.7 & (4.1) \\
\hline Total of species & \multicolumn{2}{|c|}{35} & & \multicolumn{2}{|c|}{25} \\
\hline \multicolumn{6}{|c|}{ Individuals/colonies per inlet } \\
\hline Carcinus maenas & 376 & $(174)$ & - & 935 & $\{274\}$ \\
\hline Crangon crangon & 988 & (611) & & 1700 & $(726)$ \\
\hline Liocarcinus holsatus & 61 & $(33)$ & - & 15 & (9) \\
\hline Pagurus bernhardus & 598 & (268) & - & 12 & (17) \\
\hline Barnacle colonies & 1448 & (1620) & & 897 & $(1188)$ \\
\hline Cerastoderma edule & $<1$ & (1) & & 47 & $(113)$ \\
\hline Mytilus edulis & 37 & (49) & - & 2 & (3) \\
\hline Asterias rubens & 124 & (99) & & 80 & (195) \\
\hline Alcyonidium spp. & 59 & (84) & - & $<1$ & $(<1)$ \\
\hline Hydractinia echinata & 207 & $(109)$ & * & 5 & (5) \\
\hline Obelia dichotoma & 4 & $(8)$ & - & 58 & (59) \\
\hline Obelia longissima & 13 & (4) & & 50 & $(84)$ \\
\hline Metridium senile & 221 & $(258)$ & - & 8 & (12) \\
\hline
\end{tabular}


The North Frisian and the Dithmarschen Wadden Sea significantly differed in species richness per region (ANOVA; df: 1,$70 ; \mathrm{F}=30.44 ; \mathrm{p} \leq 0.001$ ) and per channel and haul (Table 1). The number of species was generally $30 \%$ lower in the south compared to the north. Within the two regions, differences in species number between channel systems were not significant. The Hörnum-Tief (Fig. 1: no. 2) was outstanding in showing the highest number of species (24 compared to the others with 8 to 20), and exhibited particularly high abundances of the hermit crab Pagurus bernhardus, the whelk $B$. undatum, a sea urchin Psammechinus miliaris, gelatinous bryozoans (Alcyonidium spp.), a hydroid (Sertularia cupressina) and the sponge Halichondria panicea (Table 2).

There was no significant trend in species number when hauls were arranged along the seaward gradient (Fig. 2). The difference in species richness between the north and the south was more pronounced inshore than further seawards.

FIG. 2

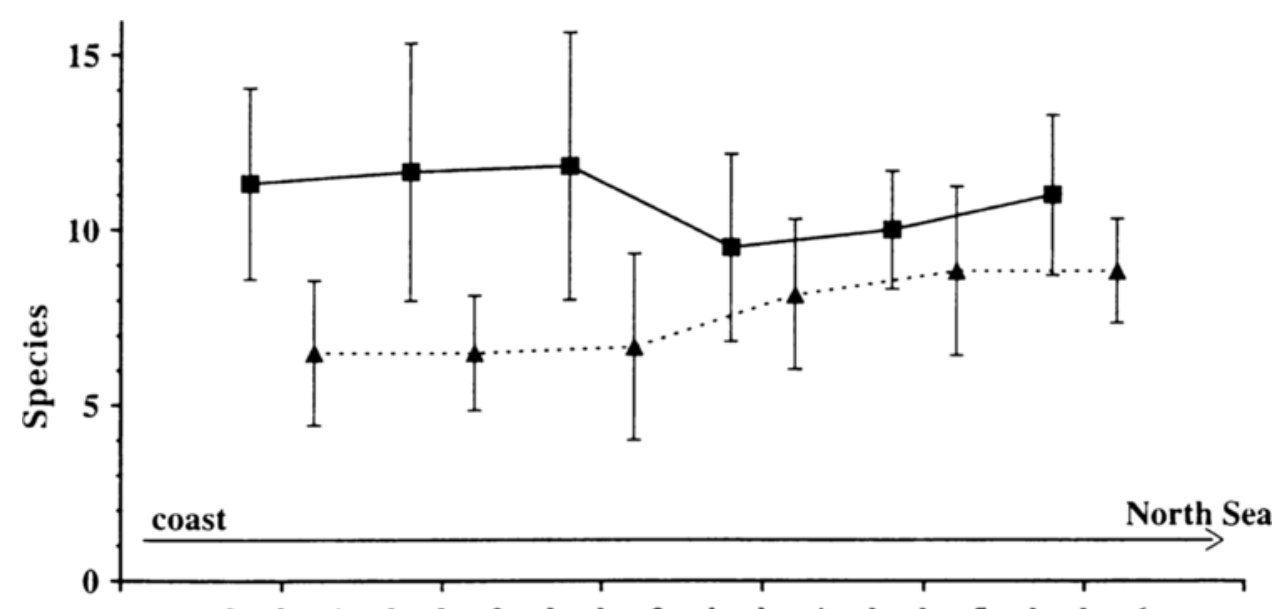

dredge 1 dredge 2 dredge 3 dredge 4 dredge 5 dredge 6

Fig. 2. Mean number of epifaunal species $( \pm \mathrm{SD})$ per dredge haul $(0.5 \mathrm{~nm})$ in the North Frisian Wadden Sea (squares; no. 1-6 in Fig. 1) and Dithmarschen Wadden Sea (triangles; no. 7-12), arranged from inshore to the most seaward haul along each channel, July 1988

Stratified sampling of tidal channels near the island of Sylt

The channels north and south of Sylt were selected to study the variation of epifaunal distribution with depth. The 1988 and 1992 surveys were similar in species composition and relative abundances within sites (Tables 2 and 3; to obtain equivalent numbers, divide those in Table 3 by a factor of 2.7). None of the species declined. Mussels (Mytilus edulis), slipper limpets (Crepidula fornicata), sea urchins (Psammechinus miliaris) and bryozoans (Alcyonidium spp.) became more abundant from 1988 to 1992 . The 1992 survey revealed that the channels north and south of Sylt differed significantly (Table 4). 
Table 2. Epifauna (>1 cm) in 6 dredge hauls of $0.5 \mathrm{~nm}$ each, taken from 12 tidal channels in the Wadden Sea of Schleswig-Holstein (see Fig.1) in July 1988; broken line separates northern and southern subregions. Taxa with $\geq 10$ individuals / colonies in the total catch are presented; mean and total numbers of species include rare species, too. Fish and medusae are not included

\begin{tabular}{|c|c|c|c|c|c|c|c|c|c|c|c|c|}
\hline \multirow[b]{2}{*}{ Tidal inlet no. (see Fig. 1) } & \multicolumn{6}{|c|}{ North Frisian Wadden Sea } & \multicolumn{6}{|c|}{ Dithmarschen Wadden Sea } \\
\hline & 1 & 2 & 3 & 4 & 5 & 6 & 7 & 8 & 9 & 10 & 11 & 12 \\
\hline \multicolumn{13}{|l|}{ Crustacea: } \\
\hline Carcinus maenas & 400 & 688 & 307 & 410 & 252 & 198 & 1098 & 1013 & 1244 & 1014 & 768 & 475 \\
\hline Crangon crangon & 1654 & 360 & 413 & 777 & 1795 & 929 & 1838 & 1847 & 1994 & 994 & 764 & 2763 \\
\hline Eriocheir sinensis & & & & & & & & & & 1 & 4 & 34 \\
\hline Hyas araneus & & 21 & 2 & & 1 & 7 & & & & & & \\
\hline Liocarcinus holsatus & 74 & 20 & 67 & 49 & 114 & 40 & 9 & 21 & 29 & 17 & 9 & 6 \\
\hline Pagurus bernhardus & 624 & 1040 & 459 & 752 & 400 & 315 & 15 & 1 & 45 & 11 & & \\
\hline Pandalus montagui & & 5 & 3 & & & 15 & & & & & & \\
\hline Barnacle colonies & 600 & 1186 & 381 & 4645 & 465 & 1410 & 84 & 1142 & 3158 & 749 & 90 & 159 \\
\hline Sacculina carcini & & 3 & 4 & 17 & 28 & 39 & 11 & 16 & 15 & 2 & 2 & \\
\hline \multicolumn{13}{|l|}{ Mollusca: } \\
\hline Cerastoderma edule & & & & & 2 & 2 & & 2 & 277 & & & \\
\hline Macoma balthica & & & & & & & 49 & 2 & 4 & & 1 & 5 \\
\hline Mytilus edulis & 7 & 16 & 16 & 30 & 17 & 136 & 6 & 1 & 4 & & & \\
\hline Buccinum undatum & & 140 & 15 & 1 & & & & & & & & \\
\hline Littorina littorea & 2 & & 18 & 2 & & 24 & & & & & & \\
\hline \multicolumn{13}{|l|}{ Echinodermat $a:$} \\
\hline Asterias rubens & 14 & 290 & 105 & 58 & 91 & 187 & & 2 & 478 & & 2 & \\
\hline Psammechinus miliaris & & 82 & & & & & & & & & & \\
\hline \multicolumn{13}{|l|}{ Bryozoa: } \\
\hline Alcyonidium spp. & 32 & 225 & 53 & 39 & 2 & 4 & & & 1 & & & \\
\hline Crisia eburnea & & & & & & & & & & & 15 & \\
\hline Electra pilosa & 1 & 4 & & & & & & & & 2 & 30 & \\
\hline Flustra foliacea & 1 & & & & 1 & & & & 2 & 2 & 15 & \\
\hline \multicolumn{13}{|l|}{ Membranipora } \\
\hline membranacea & 19 & & & & & 1 & & 1 & & & & \\
\hline \multicolumn{13}{|l|}{ Coelenterata: } \\
\hline Hydractinia echinata & 257 & 277 & 117 & 341 & 204 & 47 & 12 & 7 & 6 & 2 & & \\
\hline Obelia dichotoma & & & & 6 & 1 & 19 & 59 & 55 & 1 & 11 & 53 & 168 \\
\hline Obelia longissima & 18 & 17 & 9 & 9 & 8 & 14 & 15 & 220 & 37 & 15 & 10 & 2 \\
\hline Sertularia cupressina & 1 & 25 & & & & & & & & & & \\
\hline Metridium senile & 6 & 18 & 2 & 442 & 253 & 606 & & & 12 & 31 & 4 & \\
\hline Sagartia troglodytes & 2 & 1 & & & 12 & 52 & & 1 & 7 & & & \\
\hline $\begin{array}{l}\text { Por if er a: } \\
\text { Halichondria panicea }\end{array}$ & & 21 & & & & & & & & & & \\
\hline Mean species number & 10.2 & $\begin{array}{l}12.7 \\
(3.9)\end{array}$ & $\begin{array}{l}10.3 \\
-129)\end{array}$ & 9.8 & $\begin{array}{l}11.3 \\
(2.0)\end{array}$ & $\begin{array}{l}11.0 \\
(2.8)\end{array}$ & $\begin{array}{c}7.2 \\
(2.4)\end{array}$ & $\begin{array}{c}7.7 \\
(1.4)\end{array}$ & $\begin{array}{l}10.8 \\
(1.5\end{array}$ & $\begin{array}{c}7.5 \\
(0.8)\end{array}$ & $\begin{array}{c}6.7 \\
(1.9)\end{array}$ & $\begin{array}{c}5.7 \\
(1.5)\end{array}$ \\
\hline Total species number & 19 & 24 & 18 & 15 & 20 & 20 & 11 & 16 & 20 & 13 & 14 & 8 \\
\hline
\end{tabular}


Table 3. Epifauna $(>1 \mathrm{~cm})$ in 30 dredge hauls of $0.5 \mathrm{~km}$ each, taken from tidal channels north and south of Sylt in May and July 1992. Hoyer Dyb was sampled in July only. For further explanations, see Table 1

\begin{tabular}{|c|c|c|c|c|c|}
\hline \multirow[b]{2}{*}{ Tidal inlet no. (see Fig. 1) } & \multicolumn{2}{|c|}{ May 1992} & \multicolumn{3}{|c|}{ July 1992} \\
\hline & $\begin{array}{c}\text { Lister } \\
\text { Ley } \\
1\end{array}$ & $\begin{array}{c}\text { Hörnum- } \\
\text { Tief } \\
2\end{array}$ & $\begin{array}{c}\text { Hoyer } \\
\text { Dyb } \\
1^{*}\end{array}$ & $\begin{array}{l}\text { Lister } \\
\text { Ley } \\
1\end{array}$ & $\begin{array}{c}\text { Hörnum- } \\
\text { Tief } \\
2\end{array}$ \\
\hline \multicolumn{6}{|l|}{ Crustacea: } \\
\hline Cancer pagurus & 16 & 17 & 5 & 2 & 8 \\
\hline Carcinus maenas & 427 & 309 & 394 & 696 & 958 \\
\hline Crangon crangon & 6060 & 1811 & 5320 & 3794 & 12562 \\
\hline Hyas araneus & 9 & 55 & 1 & 3 & 6 \\
\hline Liocarcinus holsatus & 158 & 72 & 42 & 55 & 67 \\
\hline Pagurus bernhardus & 972 & 1402 & 1046 & 434 & 1479 \\
\hline Pandalus montagui & & 16 & & 1 & 6 \\
\hline Balanus crenatus colonies & 3181 & 942 & 540 & 861 & 898 \\
\hline Sacculina carcini & 2 & & 3 & 8 & 19 \\
\hline \multicolumn{6}{|l|}{ Mollusca: } \\
\hline Mytilus edulis & 269 & 56 & 6 & 467 & 18 \\
\hline Aeolidia papillosa & 2 & 9 & & & 6 \\
\hline Buccinum undatum & 11 & 413 & 3 & 4 & 191 \\
\hline Crepidula fornicata & 179 & 242 & 99 & 176 & 209 \\
\hline Lepidochitona cinerea & 8 & 2 & & 7 & 1 \\
\hline Onchidoris muricata & & 48 & & & \\
\hline \multicolumn{6}{|l|}{ Echinodermata: } \\
\hline Asterias rubens & 254 & 677 & 49 & 263 & 431 \\
\hline Psammechinus miliaris & 3 & 1069 & 1 & 21 & 507 \\
\hline \multicolumn{6}{|l|}{ B г у о z о а: } \\
\hline Alcyonidium gelatinosum & & 41 & 5 & 2 & 191 \\
\hline Alcyonidium cf. mytili & 513 & 856 & 314 & 663 & 1185 \\
\hline Electra pilosa & 10 & 50 & 4 & 1 & 16 \\
\hline $\begin{array}{l}\text { Co e l e n te r a t a: } \\
\text { Hydractinia echinata }\end{array}$ & \multicolumn{4}{|c|}{ Coelenterata: } & 440 \\
\hline Hydrallmania falcata & & 18 & 10 & 201 & \\
\hline Obelia longissima & 190 & 588 & 14 & 46 & 230 \\
\hline Metridium senile & 206 & 443 & 42 & 393 & 658 \\
\hline Sagartia troglodytes & 19 & 75 & 1 & 2.2 & 22 \\
\hline Sagartiogeton undatus & 15 & 41 & & 11 & 30 \\
\hline Sertularia cupressina & 4 & 146 & & 1 & 162 \\
\hline Tubularia indivisa & & 14 & & & 2 \\
\hline Tubularia larynx & & 6 & 12 & 3 & 5 \\
\hline Scyphozoa polyps & & & & & 175 \\
\hline \multicolumn{6}{|l|}{ Polychaeta: } \\
\hline Pomatoceros triqueter & & 13 & 1 & & 7 \\
\hline Sabellaria spinulosa & & 20 & & & 11 \\
\hline \multicolumn{6}{|l|}{ Por if era: } \\
\hline Halichondria panicea & & 33 & & & 25 \\
\hline Mean species number & 10.1 & 16.4 & 8.7 & 10.4 & 15.7 \\
\hline$( \pm \mathrm{SD})$ & $(3.0)$ & (5.3) & $(2.6)$ & $(3.0)$ & $(5.1)$ \\
\hline Total species number & 25 & 36 & 24 & 26 & 35 \\
\hline
\end{tabular}


Table 4. Mean and SD of species numbers and abundances of dominant epifauna $(>1 \%)$ in channels north (90 dredge hauls) and south (60 hauls) of Sylt. For further explanations, see Table 2

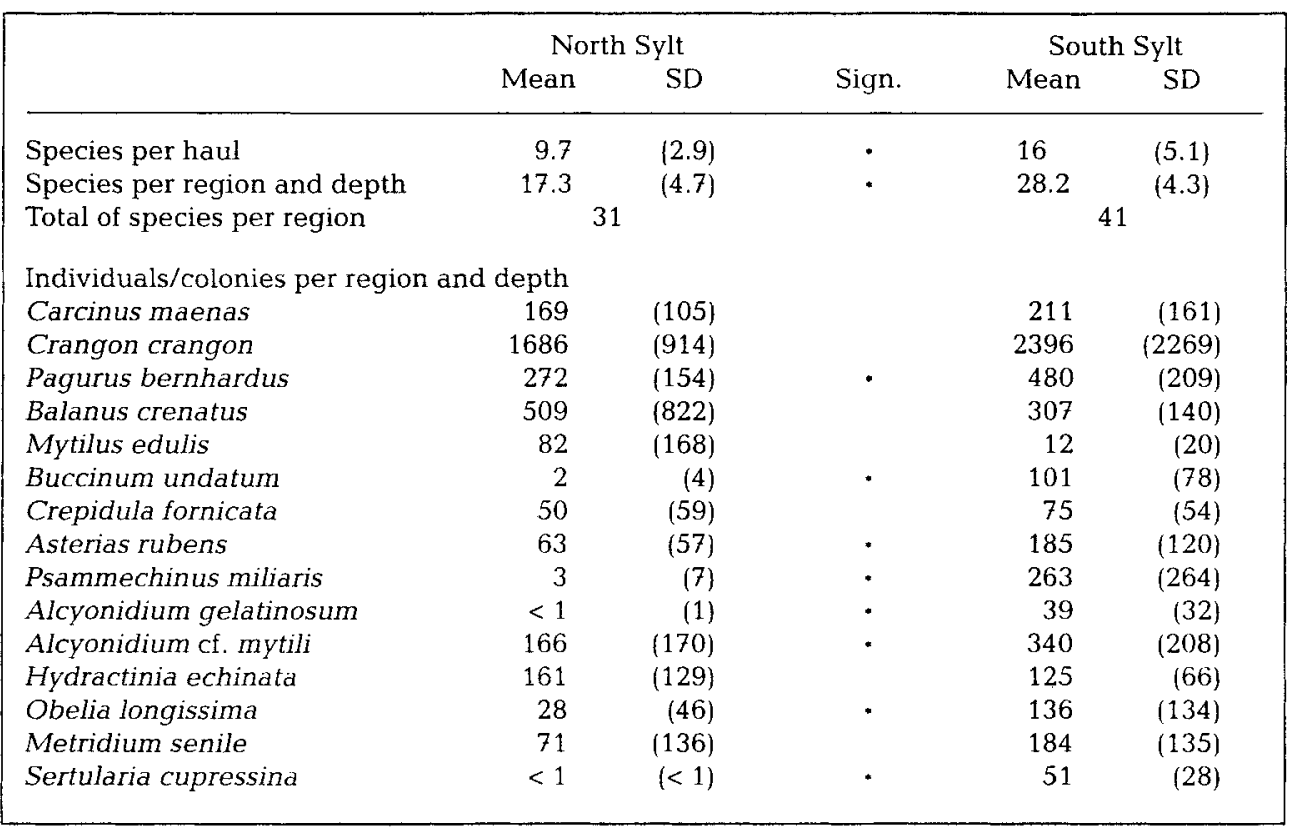

Species richness was higher in the south (ANOVA; df:1, 148; $F=91.64 ; p \leq 0.001)$. Eight of the dominant species were more abundant south and none north of Sylt (Table 4). Crustaceans dominated at both sites, but in the south the sessile and slow moving epifauna attained a much higher share.

South of Sylt, the depth distribution of the epibenthos revealed higher abundances, species richness and total species number along the slopes (5 and $10 \mathrm{~m}$ ) compared to the deepest parts $(15 \mathrm{~m}$ ) of these channels (Fig. 3). In general, the deepest parts of the investigated channels seem to be less suitable for the epibenthos. Abundant clumps of mussels at a depth of $5 \mathrm{~m}$ in Lister Ley increased species richness along this gentle upper slope (hauls with and without mussels tested with Mann \& Whitney U-test, p $\leq 0.001$ ). The presence of scattered pleistocene boulders and abundant stones in Hörmum-Tief (nautical map No. 107 of the Bundesamt für Seeschiffahrt und Hydrographie, 1992; see also Möbius, 1893; Hagmeier \& Kändler, 1927; Hagmeier, 1941; Lüneburg, 1968) is another correlate of high epifaunal abundance and diversity. Only in Hörnum-Tief did we catch a few individuals of the horse mussel Modiolus modiolus. 
North of Sylt
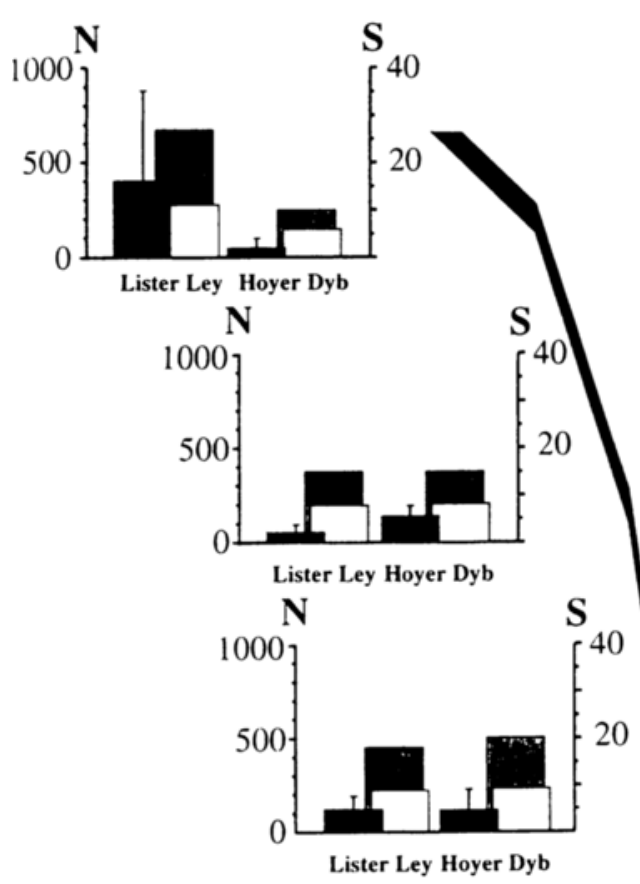

South of Sylt

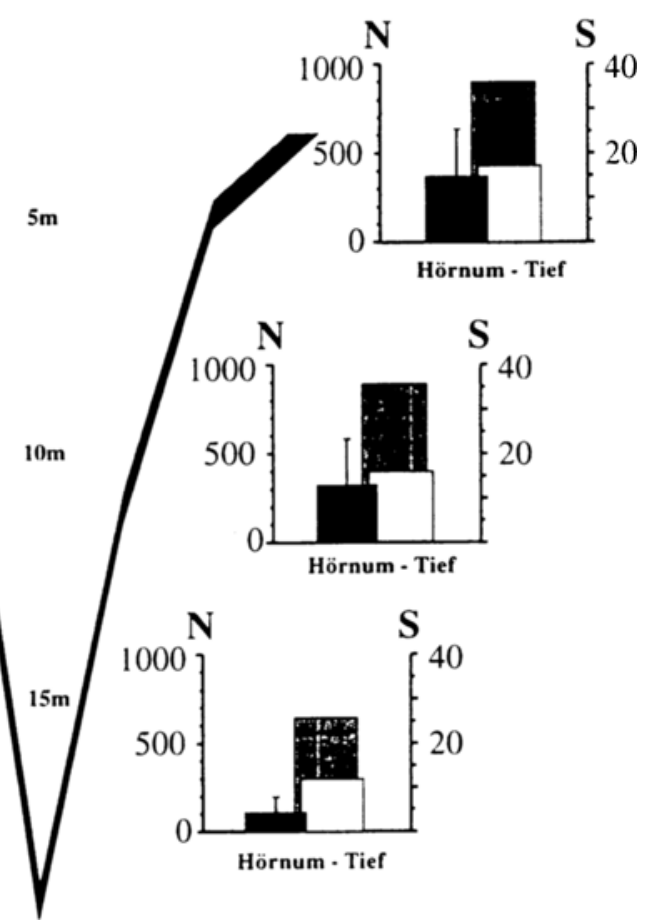

Fig. 3. Mean abundance ( $N$, black bars $+S D$ ) and mean number of species ( $S$, white bars $+S D$ ) $500 \mathrm{~m}^{-2}$, sum of species from two months in 1992 ( $\mathrm{S}$, grey bars) sampled at 5,10 and $15 \mathrm{~m}$ depth. Based on 20 dredge hauls in Hörnum-Tief and Lister Ley, and on 10 hauls in Hoyer Dyb. Fish and shrimp are not included

\section{DISCUSSION}

\section{Tidal channels are distinct epifaunal habitats}

Tidal inlets ramify into channels towards the land and fan out into a shallow ebb tidal delta towards the North Sea (Ehlers, 1988). The tidal channels constitute distinct geomorphological and hydrological structures of the Wadden Sea, transporting the ebbing waters from the intertidal flats through the tidal inlet to the adjacent North Sea and the flooding waters back to the flats. Currents in the channels can be faster $\left(0.7\right.$ to $\left.1.5 \mathrm{~m} \mathrm{sec}^{-1}\right)$ than above tidal flats and in the North Sea $\left(<0.7 \mathrm{~m} \mathrm{sec}^{-1}\right)$. These channels may be regarded as marine rivers, 10 to $30 \mathrm{~km}$ in length and up to $2 \mathrm{~km}$ in width. Average depth is 5 to $15 \mathrm{~m}$. They represent a habitat with physical properties different from their surroundings, and they also provide an intricate link between the shallow flats further inshore and the offshore North Sea.

Accordingly, the benthos of the tidal channels is composed of some specific elements combined with several others which are shared with the tidal flats and/or the North Sea 
(Hagmeier \& Kändler, 1927; Dörjes et al., 1969). Oyster beds and Sabellaria-reefs were regarded by Hagmeier \& Kändler (1927) as the most characteristic benthic features of the tidal channels at that time. In a more recent study, Reise \& Bartsch (1990) encountered neither of these, but noted that the epibenthos of tidal channels was dominated by mobile crustaceans and sessile mussels, whereas the epibenthos in the adjacent North Sea was entirely dominated by echinoderms.

The mobile epibenthos of the tidal channels consists in part of tidal, seasonal or optional migrants from the shallow flats (Janssen \& Kuipers, 1980; Klein Breteler, 1976; Reise, 1985). Often juveniles prevail on tidal flats and adults in tidal channels, i.e. in Crangon crangon, Carcinus maenas, Pagurus bernhardus. In the present study, these migrating decapod crustaceans dominated the epifauna in all 12 channel systems investigated. The barnacle Balanus crenatus was the most abundant sessile suspension feeder, attached to living (i. e. mussels and crabs) as well as to non-living hard substrates (mainly mollusc shells). On the tidal flats this species gives way to Semibalanus balanoides (Albrecht \& Reise, 1994), and in the North Sea it is significantly less abundant than in the tidal channels (Reise \& Bartsch, 1990). In addition to these dominants, some epifaunal species were encountered in tidal channels which do not commonly occur either on tidal flats or in the adjacent North Sea (see also Reise \& Bartsch, 1990). It may be concluded that, albeit of historical change, the tidal channel epifauna should be regarded as a distinct ecotone biota, constituting a characteristic feature of the Wadden Sea.

\section{Northern and southern tidal channels}

In addition to epifaunal components shared by all tidal channels, this study suggests a distinction between two types of channels, those adjacent to the mouth of the Elbe river and those further north, separated from the Elbe estuary by the Eiderstedt peninsula. This is inferred from significant differences in species richness and species abundances between the northern and southern channel systems. Four environmental factors may contribute to this subdivision: salinity and pollution, shelter and sediment. The rivers entering the southern Wadden Sea of Schleswig-Holstein cause salinity to be lower and more variable than in the northern part. This estuarine factor may cause a net decrease in species numbers (Remane, 1934; Wolff, 1983). In estuaries the loss of species is often compensated for by higher abundances of those which remain. This was first proposed by Dahl (1893). The epifauna does not seem to follow this rule, except for a higher abundance of Carcinus maenas in the southern, estuarine channels. This may constitute a relief from competition with Pagurus bernhardus, abundant in the more marine channels further north. However, the negative correlation between these two crabs is not significant (Spearman rank coefficient $r_{s}=0.446, P>0.05$ ), and experiments on interactions between shore crabs and hermit crabs have not yet been performed.

The same rivers which cause salinity to be lower and more variable in the southern than in the northern region of the Schleswig-Holstein Wadden Sea are also major sources of pollution. Reviews on heavy metals and chlorinated hydrocarbons in fish of the Wadden Sea clearly show highest concentrations in the Elbe estuary (Harms, 1994; Westernhagen, 1994). Also nutrient concentrations are much higher in the waters off the Dithmarschen coast than in the North Frisian Wadden Sea (Hesse et al., 1992). Although effects on the epibenthic organisms in the tidal channels have not been studied, pollu- 
tion may be assumed to account for some of the differences in epifauna between the southern and northern channels. Tiews (1983) suggested that an observed long-term decline in some fish species in the by-catch of the shrimp fishery off the Dithmarschen coast may be due to pollution.

Salinity and pollution are unlikely to be the only causes of epifaunal differences between the southern and the northern channels. Few Mytilus edulis were dredged in the southern channel systems, although mussels are known to occur within the Elbe estuary where artificial rock allows attachment (Caspers, 1951). Furthermore, mussels are common in the western Dutch Wadden Sea (Dekker, 1989) where the proximity to the river Rhine causes salinities similar to those at the Dithmarschen coast. Nehls \& Thiel (1993) documented a high susceptibility of intertidal mussel beds to storm events. Persistent beds were confined to the shelter of islands in the North Frisian Wadden Sea. Only one bed occurred off the Dithmarschen coast. We here suggest that the natural barrier against swell and waves from the North Sea benefits mussels and other sessile epifauna in the northern channels, while no such shelter protects the epifauna in the southern channels.

Erosion of pleistocene moraines delivered coarse sand, pebbles and even some boulders to the sediments of the tidal channels north of Eiderstedt peninsula, while further south the sediments are fine grained throughout (see Lüneburg, 1968; Figge, 1981). Although shell gravel is available for attachment of sessile epifauna in all tidal channels, the stones in the northern channels may provide a more stable substrate. In addition, mobile epibenthos may find refuge underneath stones. The general conclusion is that in the northern channels a higher and less variable salinity, a wider distance from major sources of pollution, the shelter by a seaward barrier, and the presence of an interspersed hard substrate may all add up to cause a higher epifaunal diversity than in the southern channels.

In addition to the epifaunal differences between the northern and southern region of the Wadden Sea of Schleswig-Holstein described here, there are some more biotic contrasts. Beds of the oyster Ostrea edulis once covered nearly $4 \%$ of the subtidal zone in the North Frisian Wadden Sea, but apparently were absent between Eider and Elbe (Möbius, 1893). Reefs of the polychaete Sabellaria spinulosa were a common structure in the northern tidal inlets (Hagmeier \& Kändler, 1927) but were rare in the south (Richter, 1927). A recent survey revealed that only a few intertidal seagrass beds occurred off the Dithmarschen coast, while in the North Frisian region coverage was nearly $15 \%$ (Reise, 1994).

\section{Mussels, boulders and diversity}

A vertical zonation of sessile epifauna in the North Frisian tidal chanpels was proposed by Hagmeier \& Kändler (1927): mussel beds close to low water line, oyster beds from there downwards to a depth of $6 \mathrm{~m}$, and Sabellaria-reefs between 6 and $12 \mathrm{~m}$. Occasionally, oyster beds were invaded by mussels from above and by Sabellaria from below, indicating some overlap of the vertical ranges. No conspicuous epifauna was recorded from the deepest part of the gullies.

Our stratified sampling in channels north and south of the island of Sylt revealed a different pattern because oyster beds and Sabellaria-reefs were gone. Nevertheless, at the Hörnum-Tief we still encountered a rich epifauna on the slope and a poor epifauna on the bottom of the channel. Mussels remained common on the upper slopes but occurred also scattered at all depths (see also Riesen \& Reise, 1982; Reise \& Schubert, 1987). 
In 1992, clumps of mussels were only abundant at $5 \mathrm{~m}$ depth in the Lister Ley. These mussels provide suitable attachment for barnacles, Crepidula fornicata, Metridium senile, hydroids, bryozoans and some others; they also offer an attractive surface for grazers, accumulate food for deposit feeders, provide shelter and refuge within the interstices of clumps, and finally attract predators such as Carcinus maenas and Asterias rubens. This facilitation and promotion explains epifaunal richness along the upper slope of Lister Ley. In Hoyer Dyb, clumps of mussels were rare and epifauna was poorly developed. The mussel Mytilus edulis may be regarded as an 'ecosystem engineer' (sensu Lawton, 1994) in the tidal channels, a role which once was shared with Zostera marina, Ostrea edulis and Sabellaria spinulosa before these became rare or vanished from the tidal inlets near Sylt (Reise, 1982).

In 1988 the Hörnum-Tief had the highest rank in terms of species richness. In 1992 the epifauna in this channel was significantly more diverse and abundant than in the channels north of Sylt. This presumably was also the case when Möbius (1893), Hagmeier \& Kändler (1927) and Hagmeier (1941) surveyed this region. O. edulis from Hörnum-Tief was in particularly good condition and highly regarded for its excellent taste. Only from Hörnum-Tief were Modiolus modiolus, Anomia ephippium, Echinus esculentus, Alcyonium digitatum, Lithothamnium spec. recorded. Exploitation of the hydroid Sertularia cupressina was particularly rewarding in Hörnum-Tief (Wagler \& Berghahn, 1992).

Although our survey showed that the former seagrass beds, oyster beds and reefs of Sabellaria were completely gone, the Hörnum-Tief still remained richer in epifauna than the other tidal channels, evidenced by rare species such Modiolus modiolus, Onchidoris muricata, Hydrallmania falcata, Tubularia indivisa, Pomatoceros triqueter, solitary Sabellaria spinulosa and high abundances of Psammechinus miliaris, Hyas araneus and Buccinum undatum, particularly along the slopes. Thus, the cause of high diversity seems to have persisted. The only physical factor which sets the Hörnum-Tief apart is a high abundance of pebbles and boulders. We cannot quantify this bottom property but the frequent scars and dents received by our sampling gear at Hörnum-Tief testify to the abundance of hard obstacles (see also Lüneburg, 1968).

This may also explain the relative scarcity of shrimp-trawling in Hörnum-Tief because an expected catch may be outweighed by the potential damage to the gear. A similar coincidence of high species richness of epifauna, of abundant boulders, and scarcity of bottom-trawling was observed at 'Steingrund' near the island of Helgoland, about $60 \mathrm{~km}$ SW of Hörnum-Tief (Kühne \& Rachor, 1996). Pebbles and boulders may promote epifauna (1) directly by providing attachment or hiding places, (2) indirectly by keeping bottom-trawling partly away from such areas or (3) by a synergistic effect of both.

\section{Historical decline of epifauna}

Snap-shot surveys of epifauna separated by decades do not only reveal long-term changes but also include short-term effects. However, previous records spanned several years: 1869-1891 (Möbius, 1893); 1923-1926 (Hagmeier \& Kändler, 1927); 1932 and 1938-1940 (Hagmeier, 1941). Our recent data set includes dredge hauls from 1980, 1985-1988 and 1992 (Riesen \& Reise, 1982; Reise \& Schubert, 1987; Reise \& Bartsch, 1990; this survey). Severe winters exhibited the strongest environmental effect on benthic dynamics in the North Sea (Beukema, 1979, 1985; Buhr, 1981; Dörjes, 1980; Ziegelmeier, 
1964). With regard to duration, winters since 1900 with $>50$ days of ice cover in the German Wadden Sea occurred in 1923/24, 1928/29, 1939 to $1942,1946 / 47,1962 / 63,1969 / 70$ (Koslowski, 1989). According to this measure, the earlier survey periods in this century include more severe winters than our recent surveys. However, the winter 1978/79 with 48 days of ice cover lasted until late in March and strongly affected the epibenthos. For example near Sylt, Psammechinus miliaris and Crepidula fornicata almost vanished, and did not return to previous population size until the surveys in 1988 and 1992, respectively (own observation). Although duration of ice cover is only one aspect of winter severity to be noted when making comparisons, we may conclude that the effects of winters are inherent in previous and recent data sets, and do not bias our long-term comparison.

A loss of approximately one quarter and a decline in almost half of the epifaunal species have occurred during the last 100 years (Table 5). Sessile and slow-moving animals have declined, while fast-moving decapod crustaceans have persisted (see also Reise et al., 1989). This differential long-term response suggests that mechanical disturbances such as dredging for oysters and mussels, seagrass and hydroids, bottom-trawling for flatfish and shrimp, extraction of gravel and the like had and partly still have an impact.

Dredging for oysters was practiced for at least 400 years, was intensified in the $1870 \mathrm{~s}$ when the oyster market expanded, and again in 1910 when a paddle wheeler with several dredges was employed, and then eventually ceased in the 1920 s because the exhausted beds failed to recover (Reise, 1980; Neudecker, 1990). This dredging presumably did not harm the oyster population alone, but also the other sessile epibenthos.

Mussel fishery was minor until the 1940s (Hagmeier, 1941), remained rather local until the 1980s, when intensity increased threefold (Ruth \& Asmus, 1994). In additition to exploitation of natural beds, small mussels were transferred to culture lots on the upper slopes of tidal channels, where a maximum growth was expected. All lots together cover an area of $28 \mathrm{~km}^{2}$ (1989) in the shallow subtidal zone of the Wadden Sea of SchleswigHolstein (northern region only). Selected lots are usually cleared of all other epibenthos by raking the epistratum downslope. During their growth, mussels are occasionally scattered anew on these bottom cultures, and the accumulated mud is dispersed. Harvesting occurs before a succession to a rich epifaunal assemblage is completed. In general, the practice of mussel fishery promotes mussel abundance at the cost of other epifauna.

Harvesting of seagrass in the shallow subtidal was a common practice but the evidence is mainly anecdotal. Dredging for hydroids was a thriving endeavour near Büsum at the turn of this century, and later also in Hörnum-Tief. Here the last harvest was taken in 1971 (Lozán, 1994; Wagler \& Berghahn, 1992). Chains of iron were wrapped with barbed wire to entangle hydroids when pulled over the sea floor. This method was essentially detrimental to all other epibenthos too.

Trawling for shrimp (Crangon crangon) in the tidal channels of the Schleswig-Holstein Wadden Sea started in 1865, first by sailing, and at the turn of the century motorized shrimping took over. Trawling along the slopes of channels, particularly in the vicinity of beds of the polychaete Lanice conchilega and of reefs of Sabellaria spinulosa were most rewarding (Tiews, 1953). The effect of bottom-trawling in tidal channels is a repetitive disruption of the epistratum where the sessile organisms are attached. Marketable shrimp comprise 10 to $20 \%$ of the total catch (Andrew \& Pepperell, 1992). Survival of by- 
Table 5. Frequencies of epifaunal species in tidal channels near Sylt. Only species considered in the earlier surveys are included. Categories are adopted from Hagmeier \& Kändler (1927): ++ regular occurrence; + occurrence in about half of samples; \pm rare occurrence; symbol missing indicates that the species was not found; (2) recorded from Hörnum-Tief only. Frequencies (\%) for this survey are based on the sum of individuals/colonies dredged in the 2 inlets (12 hauls) in 1988, and at $5 \mathrm{~m}$ depth (sites of former oyster beds; 30 hauls in the north, 20 in the south) in 1992. Occurrences of Sagartia troglodytes and Sagartiogeton undatus are summarized, due to taxonomic ambiguities in former years. Mobile $(m)$ and sessile $(s)$ modes of life are indicated

\begin{tabular}{|c|c|c|c|}
\hline & $\begin{array}{c}\text { Möbius } \\
(1877,1893)\end{array}$ & $\begin{array}{l}\text { Hagmeier \& Kändler } \\
\text { (1927) }\end{array}$ & $\begin{array}{c}\text { These surveys } \\
(1988,1992)\end{array}$ \\
\hline \multicolumn{4}{|l|}{ Crustacea } \\
\hline Carcinus maenas (m) & ++ & ++ & (98) \\
\hline Hyas araneus (m) & +t & ++ & $(30)$ \\
\hline Liocarcinus holsatus (m) & + & ++ & $(66)$ \\
\hline Pagurus bernhardus (m) & ++ & +t & $++\quad(100)$ \\
\hline Balanus crenatus (s) & + & ++ & $++\quad(100)$ \\
\hline \multicolumn{4}{|l|}{ Mollusca } \\
\hline Mytilus edulis (s) & ++ & + & $(26)$ \\
\hline Modiolus modiolus (s) & $+(2)$ & $+(2)$ & (5) \\
\hline Ostrea edulis (s) & ++ & $t+$ & \\
\hline Buccinum undatum $(\mathrm{m})$ & ++ & ++ & $(48)$ \\
\hline Lepidochitona cinerea $(m)$ & + & ++ & $(8)$ \\
\hline \multicolumn{4}{|l|}{ Echinodermata } \\
\hline Asterias rubens $(\mathrm{m})$ & ++ & t+ & $(74)$ \\
\hline Psammechinus miliaris (m) & ++ & ++ & (39) \\
\hline \multicolumn{4}{|l|}{ Coelenterata } \\
\hline Dynamena pumila (s) & + & & \\
\hline Eudendrium rameum (s) & + & $+(2)$ & (3) \\
\hline Halecium halecinum (s) & + & + & \\
\hline Hydrallmania falcata (s) & + & + & $(2)$ \\
\hline Sertularia cupressina (s) & $+t$ & ++ & $(37)$ \\
\hline Tubularia indivisa (s) & + & \pm & (3) \\
\hline Alcyonium digitatum (s) & $\pm(2)$ & $\pm(2)$ & \\
\hline Metridium senile (s) & ++ & ++ & (51) \\
\hline Sagartiogeton undatus (s) & \pm & t+ & (30) \\
\hline Urticina felina (s) & + & ++ & \\
\hline \multicolumn{4}{|l|}{ Bryozoa } \\
\hline Alcyonidium spp. (s) & ++ & ++ & $(78)$ \\
\hline Membranipora spp. (s) & + & \pm & (7) \\
\hline \multicolumn{4}{|l|}{ Polychaeta } \\
\hline Dodecaceria concharum (s) & ++ & t+ & \\
\hline Pomatoceros triqueter (s) & $+(2)$ & $+(2)$ & (13) \\
\hline $\begin{array}{l}\text { Sabellaria spinulosa }(s) \text { - } \\
\text { 'reef '-clumps }\end{array}$ & ++ & ++ & $(12)^{*}$ \\
\hline \multicolumn{4}{|l|}{ Porifera } \\
\hline Cliona celata (s) & ++ & ++ & \\
\hline Halichondria panicea (s) & ++ & ++ & (14) \\
\hline All species & 29 & 28 & 22 \\
\hline Sessile species & 21 & 20 & 14 \\
\hline • $=$ solitary individuals & & & \\
\hline
\end{tabular}


catch varies among species; however, with regard to sessile epibenthos, hardly any is capable of attaching anew and the chance of being discarded at a site and in a position suitable for continued growth is rather low.

Local shrimping was fairly intensive in the Wadden Sea of Schleswig-Holstein. Off Büsum in 1951, a fleet of 80 to 90 ships trawled an area of $160 \mathrm{~km}^{2}$ (Tiews, 1953). This is a ratio of $2 \mathrm{~km}^{2}$ per ship. In 1994, there were 106 ships registered for shrimp fishery in Schleswig-Holstein (Gubernator, 1994). With a beamtrawl width of $2 \times 9 \mathrm{~m}$ and a towing velocity of 3 knots, about $0.1 \mathrm{~km}^{2} \mathrm{~h}^{-1}$ are raked by each ship. Assuming $8 \mathrm{~h}$ of shrimping during each of 140 days in the course of a year, nearly $12000 \mathrm{~km}^{2}$ are raked by the entire fleet. With an acquisition of stronger vessels in recent years, trawling for shrimp shifted from the tidal channels to the coastal zone seaward of the barrier islands when weather conditions are benign. Even if we assume that only one third of the trawling still occurs within the tidal channels and adjacent subtidal flats of approximately $825 \mathrm{~km}^{2}$, the bottom is raked on average 5 times annually, and probably even 15 times twenty years ago when all shrimping was confined to the Wadden Sea proper. Whatever the effect of a single stroke with a rope or a full net, it is the cumulative disturbance which is harmful to sessile epibenthos. Recovery through larval import from the North Sea may be limited, considering the damage caused to the epibenthos by the trawling for demersal fish there (cf. Rauck, 1985; Lindeboom, 1995).

Considering all of these mechanical disturbances of the epifauna in the tidal channels during the last hundred years, the loss of major assemblages and a decline of nearly one half of all species may not be surprising (see also Nordheim et al., 1996). Although other factors, such as pollution, may also have contributed to the observed decline, none offers a consistent explanation as to why the sessile epifauna suffered, while the mobile epifauna did not. This can only be explained by taking all in all the various disturbances caused by the fishery. To obtain more direct evidence, selected tidal channels in both regions of the Schleswig-Holstein Wadden Sea should be closed to the exploitation of living resources, and those left open may serve as controls. A long-term experiment of this kind may be justified given the dramatic species decrease in the tidal channels of the Wadden Sea of Schleswig-Holstein.

Acknowledgements. We thank the crew of the R. V. 'Mya', N. Kruse and P. Elvert for 222 dredge hauls. H. Michaelis and E. Rachor significantly improved the manuscript. This study was supported by the Federal Environmental Agency, the Environmental Natural Research Plan of the Minister for the Environment, Nature Conservation and Nuclear Safety of the Federal Republic of Germany (grant 10802 085/01) and the State of Schleswig-Holstein. This is publication no. 274 of the project 'Ecosystem Research Wadden Sea'.

\section{LITERATURE CITED}

Albrecht, A. \& Reise, K., 1994. Effects of Fucus vesiculosus covering intertidal mussel beds in the Wadden Sea. - Helgoländer Meeresunters. 48, 243-256.

Andrew, N. L. \& Pepperell, J. G., 1992. The by-catch of shrimp trawl fisheries. - Oceanogr. mar. Biol. $30,527-565$.

Beukema, J. J., 1979. Biomass and species richness of the macrobenthic animals living on a tidal flat area in the Dutch Wadden Sea: effects of a severe winter. - Neth. J. Sea Res. 13, 203-223.

Beukema, J. J., 1985. Zoobenthos survival during severe winters on high and low tidal flats in the Dutch Wadden Sea. In: Marine biology of polar regions and effects of stress on marine organisms. Ed. by J. S. Gray \& M. E. Christiansen. Wiley, Chichester, 351-361. 
Buhr, K-J., 1981. Auswirkungen des kalten Winters 1978/79 auf das Makrobenthos der Lanice-Siedlung im Weser-Ästuar. - Veröff. Inst. Meeresforsch. Bremerh. 19, 115-131.

Caspers, H., 1952. Bodengreiferuntersuchungen über die Tierwelt in der Fahrrinne der Unterelbe und im Vormündungsgebiet der Nordsee. - Zool. Anz. (Suppl.) 16, 404-418.

Dahl, F., 1893. Untersuchungen über die Thierwelt der Unterelbe. - Ber. Kommn wiss. Unters. dt. Meere $6(3), 151-185$.

Dekker, R., 1989. The macrozoobenthos of the subtidal western Dutch Wadden Sea. I. Biomass and species richness. - Neth. J. Sea Res. 23, 57-68.

Dick, S., Mittelstaedt, E. \& Müller-Navarra, S., 1992. Der küstennahe Gezeitenstrom in der Deutschen Bucht. Bundesamt für Seeschiffahrt und Hydrographie, Hamburg, 29 pp.

Dörjes, J., 1980. Auswirkung des kalten Winters 1978/1979 auf das marine Makrobenthos. - Natur Mus., Frankf. 110, 109-115.

Dörjes, J., Gadow, S., Reineck, H-E. \& Singh, I. B., 1969. Die Rinnen der Jade (Südliche Nordsee), Sedimente und Makrobenthos. - Senckenberg. marit. 50, 5-62.

Ehlers, J., 1988. The morphodynamics of the Wadden Sea. Balkema, Rotterdam, 397 pp.

Figge, K., 1981. Sedimentverteilung in der Deutschen Bucht, 1:250000. Deutsches Hydrographisches Institut, Hamburg .

Gubernator, M., 1994. Sozioökonomischer Vergleich der niedersächsischen und schleswig-holsteinischen Fischereiwirtschaft. - Infn Fischw. 41, 136-141.

Hagmeier, A., 1941. Die intensive Nutzung des nordfriesischen Wattenmeeres durch Austern- und Muschelkultur. - Z. Fisch. 39, 105-165.

Hagmeier, A. \& Kändler, R., 1927. Neue Untersuchungen im nordfriesischen Wattenmeer und auf den fiskalischen Austernbänken. - Wiss. Meeresunters. (Helgoland) 16, 1-99.

Harms, U., 1994. Regionale Muster von Schwermetallen in Küstenfischen. In: Warnsignale aus dem Wattenmeer. Ed. by J. L. Lozán, E. Rachor, K. Reise, H. von Westernhagen \& W. Lenz. Blackwell, Berlin, 234-237.

Hesse, K.-J., Hentschke, U. \& Brockmann, U., 1992. A synoptic study of nutrient and phytoplankton characteristics in the German Wadden Sea with respect to coastal eutrophication. In: Marine eutrophication and population dynamics. Ed. by G. Colombo, I. Ferrari, V. U. Ceccerelli \& R. Rossi. Olsen \& Olsen, Fredensborg, 45-53.

Janssen, G. M. \& Kuipers, B. R., 1980. On tidal migration in the shrimp Crangon crangon. - Neth. J. Sea Res. 14, 339-348.

Klein Breteler, W. C. M., 1976. Migration of the shore crab, Carcinus maenas, in the Dutch Wadden Sea. - Neth. J. Sea Res. 10, 338-353.

Koslowski, G., 1989. Der Eiswinter 1988/89 im deutschen Küstengebiet zwischen Ems und Trave. Dt. hydrogr. Z. $42,17-19$.

Kühne, S. \& Rachor, E., 1996. The macrofauna of a stony sand area in the German Bight (North Sea). - Helgoländer Meeresunters. 50, 433-452.

Lawton, J. H., 1994. What do species do in ecosystems? - Oikos 71, 367-374.

Lindeboom, H. J., 1995. Protected areas in the North Sea: an absolute need for future marine research. - Helgoländer Meeresunters. 49, 591-602.

Lozán, J. L., 1994. Zur Geschichte der Fischerei im Wattenmeer und in Küstennähe. In: Warnsignale aus dem Wattenmeer. Ed. by J. L. Lozán, E. Rachor, K. Reise, H. von Westernhagen \& W. Lenz. Blackwell, Berlin, 215-226.

Lüneburg, H., 1968. Sedimenthabitus und Sedimentdynamik in den Pieprinnen vor Büsum und im Hörnum-Tief vor Sylt (Deutsche Bucht). - Veröff. Inst. Meeresforsch. Bremerh. 11, 137-164.

Metzger, A., 1871. Die wirbellosen Meerestiere der ostfriesischen Küste. - Jber. naturh. Ges. Hannover $20,22-36$.

Möbius, K., 1877. Die Auster und die Austernwirthschaft. Wiegandt, Hempel \& Parey, Berlin, 126 pp.

Möbius, K., 1893. Über die Tiere der schleswig-holsteinischen Austembänke, ihre physikalischen und biologischen Lebensverhältnisse. - Sber. preuss. Akad. Wiss. 7, 33-58.

Nehls, G. \& Thiel, M., 1993. Large-scale distribution patterns of the mussel Mytilus edulis in the Wadden Sea of Schleswig-Holstein: do storms structure the ecosystem? - Neth. J. Sea Res. 31, 181-187.

Neudecker, T., 1990. The history of the former German oyster fishery and mariculture: 400 years crown law on oyster. - Dt. hydrogr. Z. (Erg.-H. R. B.) 22, 518-525. 
Postma, H., 1983. Hydrography of the Wadden Sea. In: Ecology of the Wadden Sea: movements and properties of water and particulate matter. Ed. by W. J. Wolff. Balkema, Rotterdam, 1(2), 1-75.

Rauck, G., 1985. Wie schädlich ist die Seezungenbaumkurre für Bodentiere? - Infn Fischw. 32, $165-168$.

Nordheim, H. von, Andersen, O. N. \& Thissen, J., 1996. Red lists of biotopes, flora and fauna of the trilateral Wadden Sea area, 1995. - Helgoländer Meeresunters. 50 (Suppl.), 1-136.

Reise, K., 1980. Hundert Jahre Biozönose. - Naturw. Rdsch., Stuttg. 33, 328-335.

Reise, K., 1982. Long-term changes in the macrobenthic invertebrate fauna of the Wadden Sea: Are polychaetes about to take over? - Neth. J. Sea Res. 16, 29-36.

Reise, K., 1985. Tidal flat ecology. Springer, Berlin, $191 \mathrm{pp}$.

Reise, K., 1994. Changing life under the tides of the Wadden Sea during the 20th century. - Ophelia (Suppl.) 6, 117-125.

Reise, K. \& Bartsch, I., 1990. Inshore and offshore diversity of epibenthos dredged in the North Sea. - Neth. J. Sea Res. 25, 175-179.

Reise, K., Herre, E. \& Sturm M., 1989. Historical changes in the benthos of the Wadden Sea around the island of Sylt in the North Sea. - Helgoländer Meeresunters. 43, 417-433.

Reise, K. \& Schubert, A., 1987. Macrobenthic turnover in the subtidal Wadden Sea: The Norderaue revisited after 60 years. - Helgoländer Meeresunters. 41,69-82.

Remane, A., 1934. Die Brackwasserfauna. - Verh. dt. zool. Ges. 36, 34-74.

Richter, R., 1927. "Sandkorallen"-Riffe in der Nordsee. - Natur Mus., Frankf. 57, 49-62.

Riesen, W. \& Reise, K., 1982. Macrobenthos of the subtidal Wadden Sea: revisited after 55 years. Helgoländer Meeresunters. 35, 409-423.

Ruth, M. \& Asmus, H., 1994. Muscheln, Biologie, Bänke, Fischerei und Kulturen. In: Warnsignale aus dem Wattenmeer. Ed. by J. L. Lozán, E. Rachor, K. Reise, H. von Westernhagen \& W. Lenz. Blackwell, Berlin, 122-132.

Tiews, K., 1953. Studien zu der Büsumer Garnelenfischerei, ihren biologischen Grundlagen und ihrer wirtschaftlichen Struktur. Diss., Univ. Kiel, Kiel, $161 \mathrm{pp}$.

Tiews, K., 1983. Über die Veränderungen im Auftreten von Fischen und Krebsen im Beifang der deutschen Garnelenfischerei während der Jahre 1954-1981. - Arch. FischWiss, 34, 1-156.

Wagler, H. \& Berghahn, R., 1992. On the occurrence of white weed Sertularia cupressina L. eighteen years after giving up white weed fisheries. - Publ. Ser. Neth. Inst. Sea Res. 20, 299-301.

Westernhagen, H. von, 1994. Chlorierte Kohlenwasserstoffe in Küstenfischen. In: Warnsignale aus dem Wattenmeer. Ed. by J. L. Lozán, E. Rachor, K. Reise, H. von Westernhagen \& W. Lenz. Blackwell, Berlin, 237-241.

Wolff, W. J., 1983. Estuarine benthos. In: Estuaries and enclosed seas. Ed. by B. H. Ketchum. Elsevier, Amsterdam, 151-182.

Ziegelmeier, E., 1964. Einwirkungen des kalten Winters 1962/63 auf das Makrobenthos im Ostteil der Deutschen Bucht. - Helgoländer wiss. Meeresunters. 10, 276-282. 